\title{
Survival status of young plantations in Parbat district, Nepal
}

\begin{abstract}
G. Paudel ${ }^{1 *}$ and R. Acharya ${ }^{2}$
In Nepal, a lot of resources have been invested for establishing plantations. Due to lack of assessment of the survival status of planted seedlings, we have inadequate information about how many successful plantations that we have established in the country. This study was carried out in fourteen community forests (CFs) of Parbat district with the aim of analyzing survival status of the planted seedlings. Plantation was done in June/July 2015 and total count of the seedlings was done in June 2016. In the studied CFs, eleven species were planted comprising 20,172 seedlings in which $58.57 \%$ seedlings were survived at the end of first year. The cause of seedling mortality was identified through observation, judgment and interaction with local people. The main causes of seedling mortality $(52 \%)$ were due to small size and unhealthy seedlings, lack of care during transportation and handling. Forest fire, weeds, drought, disease and grazing were found to be responsible for the mortality of $17 \%, 12 \%, 10 \%, 7 \%$ and $2 \%$ seedlings, respectively. Regular monitoring of plantation area with the involvement of local community members is recommended for policy makers and assessment of survival rate of different species in different ecological regions is recommended for researchers.
\end{abstract}

Key words: Plantation, mortality, seedlings, survival

L arge-scale government programmes have been implemented to improve the forest resource concentrating on the creation of a new forest resource through plantation establishment (Carter and Gilmour, 1989). Forestry development is a long-term endeavour and long time is needed to get economic benefit from investment. Human patience would be exhausted to wait for until final felling of trees (Campbell and Bhattarai, 1983). Evaluation of the success of the project is required to justify the investment in the forest development. The reasonable compromise is to select short-term indicators that are as closely related to the long- term objectives as possible while still remaining measurable (Campbell and Bhattarai, 1983).

The survival rate of seedlings planted in private and government land have proved to be the most important key indicators of the success of forestry activities (Fonzen, 1986). Ghimire and Erling (1985) have similar opinion for plantations on community land in evaluating the success of the plantation project. It is necessary to track the survival rate and farmers' preference of planted seedlings to determine the effectiveness of district

forest office planting and seedling distribution programmes (Bashyal and Denmanski, 1990). Not only do they measure programme achievement, but they also point out the technical and social problems that remain to be overcome (Fonzen, 1986). In addition, survival rates by species provide an indispensable guide to the species selection for plantations in the absence of scientific research (Fonzen, 1986). Various technical and social causes regarding seedling mortality have been identified by researchers (Campbell and Bhattarai, 1990; Fonzen, 1986; Ghimire and Erling, 1985). The main technical reasons identified for seedling mortality are small size and unhealthy seedlings, mismatching species to site conditions, lack of weeding and poor plantation techniques. The main social reason in mortality of seedlings is livestock grazing, although this accounted for less mortality than technical reasons (Campbell and Bhattarai, 1983). Field level detailed analysis of the causes of mortality is essential to increase the survival rate of plantations in future which ultimately is important for justifying the investment in afforestation and reforestation activities.

\footnotetext{
Department of Forests, Babarmahal, Kathmandu, Nepal. *E-mail: ecopaudel@gmail.com

2 Freelancer Forester
} 
Nepal has planted millions of ha. of land in the past decades. But due to lack of assessment of the survival status of planted seedlings, we have inadequate information about how many successful plantations that we have established in the country. At present, there is dearth of literatures regarding the survival status of plantations. Every year millions of seedlings have been planted in Nepal. For the fiscal year 2016/17, the Government of Nepal has allocated budget of around NRs. 170 million to the Departments of Forests to produce around 23 million seedlings (DoF, 2016). Due to lack of assessment whether our plantations are successful or not, we have been unable to improve our plantation techniques. To fulfill this gap, assessment of the survival status of plantations is necessary on a regular basis. The objective of the study was to find out the survival status of different species and analyse causes of seedling mortality in community forest plantations in Parbat district.

\section{Materials and methods}

\section{Study area}

Parbat district is a hilly district of Dhaulagiri Zone, Nepal (Fig. 1). It is situated between $27^{\circ} 28^{\prime}$ $\mathrm{N}$ to $28^{\circ} 39^{\prime} \mathrm{N}$ latitude and $83^{\circ} 34^{\prime} \mathrm{E}$ to $83^{\circ} 59^{\prime} \mathrm{E}$ longitude (DFO, 2016). The altitude varies from $520 \mathrm{~m}$ to $3,300 \mathrm{~m}$ whereas the annual rainfall is $2400 \mathrm{~mm}$ to $2600 \mathrm{~mm}$. The maximum temperature in summer exceeds $32.3^{\circ} \mathrm{C}$ and the normal winter temperature is about $7.5^{\circ} \mathrm{C}$. The soils are medium to high in organic matter and are hardly suitable for agriculture in many areas. Land-slides and soil erosion are severe in Parbat district during rainy season. The total area of Parbat district is 53,668 ha, out of which agriculture land, grazing/pasture land, forest land cover $16.8 \%, 28.22 \%, 37.25 \%$, respectively and other land types cover $17.73 \%$. Major forest types in this district are hill Shorea robusta forest, Schima-Castanopsis forest, Pinus roxburghii forest and Quercus spp. forest. Most of the national forests in this district have been handed over as community forest (DFO, 2012; Paudel, 2015; Acharya and Paudel, 2016) and till now, 12, 963.56 ha of forest area has been handed over to 382 community forest user groups (DFO, 2016).
Pits of standard size $30 \mathrm{~cm} * 30 \mathrm{~cm} * 30 \mathrm{~cm}$ were prepared in April/May, 2015 and plantation was carried out in June/July, 2015. Single year seedlings provided by the District Forest Office (DFO) Parbat were planted. The plantation sites were protected from grazing. The forest users had monitored and weeded planted seedlings.

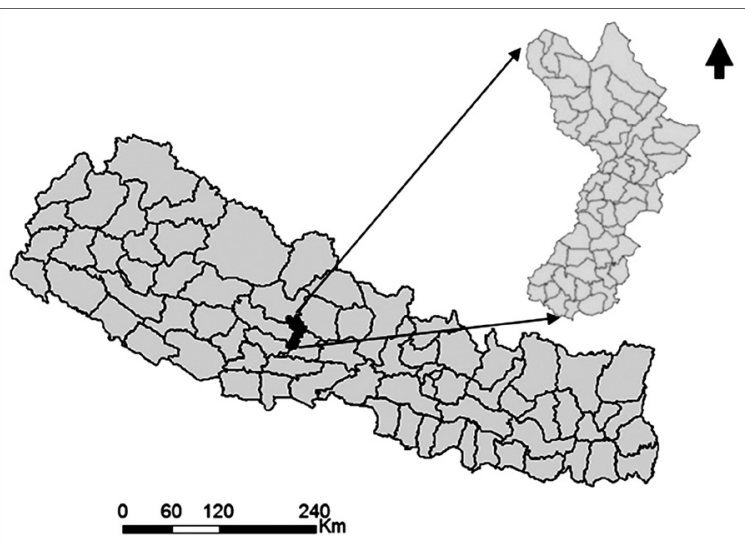

Fig. 1: Map of the study area

\section{Data collection}

The plantations done in fourteen community forests in 2015 were identified from the records of the District Forest Office (Table 1). Concerned CFs members were consulted and discussed on the assessment of the survival of planted seedlings. Total count of seedlings was done in June/July 2016 involving the users. Causes of mortality of seedlings were identified through observation, discussion with officials and interaction with local users. The data were analysed in Ms-excel.

\section{Results}

\section{Plantation survival}

Eleven tree species were planted in 14 community forests (Table 2). Altogether 20,172 seedlings were planted of which only $11,814(58.57 \%)$ were survived at the end of first year (Table 2).

\section{Causes of mortality}

The main reasons identified for seedling mortality $(52 \%)$ were due to small size and unhealthy seedlings, lack of care during transportation and handling (Fig. 2). Similarly, the natural as well as anthropogenic factors were responsible for the seedling mortality. Due to fire and drought, 
Table 1: Number of different species planted in 14 CFUGs in Parbat district

\begin{tabular}{|c|c|c|c|c|}
\hline SN & Name of the CF & Local name & Scientific name & $\begin{array}{c}\text { Seedlings } \\
\text { Planted }\end{array}$ \\
\hline 1 & Kharsubas & Louth salla & Taxus baccata & 500 \\
\hline 2 & Reshpatal & Louth salla & T. baccata & 500 \\
\hline 3 & Samekhoriya & Badhahar & Artocarpus lakoocha & 400 \\
\hline 4 & Dhulepalsing & Badhahar & A. lakoocha & 800 \\
\hline 5 & Kalibanjar Ketichou & Badhahar & A. lakoocha & 300 \\
\hline 6 & Banpala Bhumesthan & Khanyu & Ficus semicordata & 400 \\
\hline 7 & Khaharesalyan & Khayer & Acacia catechu & 4000 \\
\hline 8 & Tandibisauna & Lapsi & Choerospandias axillaris & 200 \\
\hline 9 & Samekhoriya & Lapsi & C. axillaris & 500 \\
\hline 10 & Gairakharka & Lapsi & C. axillaris & 100 \\
\hline 11 & Banpala Bhumesthan & Lapsi & C. axillaris & 200 \\
\hline 12 & Ek salle & Lekchamp & Michalia champaca & 5000 \\
\hline 13 & Paitedhanda & Lekali salla & Pinus wallichiana & 600 \\
\hline 14 & Tandibisauna & Nimaro & Ficus auriculata & 50 \\
\hline 15 & Chihandanda & Nimaro & F. auriculata & 200 \\
\hline 16 & Gairakharka & Nimaro & F. auriculata & 250 \\
\hline 17 & Banpala Bhumesthan & Nimaro & F. auroiculata & 400 \\
\hline 18 & Paitedhanda & Khanyu & $F$ semicordata & 350 \\
\hline 19 & Dhulepalsing & Khanyu & F. semicordata & 365 \\
\hline 20 & Kalibanjar Ketichou & Khanyu & F. semicordata & 50 \\
\hline 21 & Samekhoriya & Tejpat & Cinnamomum tamala & 500 \\
\hline 22 & Thulatauka & Tejpat & C. tamala & 200 \\
\hline 23 & Gairakharka & Tejpat & C. tamala & 200 \\
\hline 24 & Banpala Bhumesthan & Tejpat & C. tamala & 500 \\
\hline 25 & Musurabari & Timur & Zanthoxylum armatum & 1457 \\
\hline 26 & Rolah & Timur & Z. armatum & 2000 \\
\hline \multirow[t]{2}{*}{27} & Banpala Bhumesthan & Tuni & Toona ciliata & 150 \\
\hline & Total & & & 20,172 \\
\hline
\end{tabular}

Table 2: Species wise number of planted, survived seedlings and survival per cent

\begin{tabular}{lccc}
\hline Scientific name & $\begin{array}{c}\text { Number of planted } \\
\text { seedlings }\end{array}$ & $\begin{array}{c}\text { Number of survived } \\
\text { seedlings }\end{array}$ & Survival (\%) \\
\hline Taxus baccata & 1000 & 450 & 45.00 \\
Artocarpus lakoocha & 1500 & 510 & 34.00 \\
Ficus semicordata & 1165 & 411 & 35.28 \\
Acacia catechu & 4000 & 2000 & 50.00 \\
Choerospondias axillaris & 1000 & 429 & 42.90 \\
Michelia champaca & 5000 & 3750 & 75.00 \\
Pinus wallichina & 600 & 0 & 0.00 \\
Ficus auriculata & 900 & 655 & 72.78 \\
Cinnamomum tamala & 1400 & 850 & 60.71 \\
Zanthoxylum armatum & 3457 & 2670 & 77.23 \\
Toona ciliata & 150 & 89 & 59.33 \\
\hline Total & $\mathbf{2 0 , 1 7 2}$ & $\mathbf{1 1 , 8 1 4}$ & $\mathbf{5 8 . 5 7}$ \\
\hline
\end{tabular}


$17 \%$ and $10 \%$ seedlings died, respectively. The percentage of mortality of seedlings due to grazing and diseases was less than others, which were $2 \%$ and $7 \%$, respectively (Fig. 2 ).

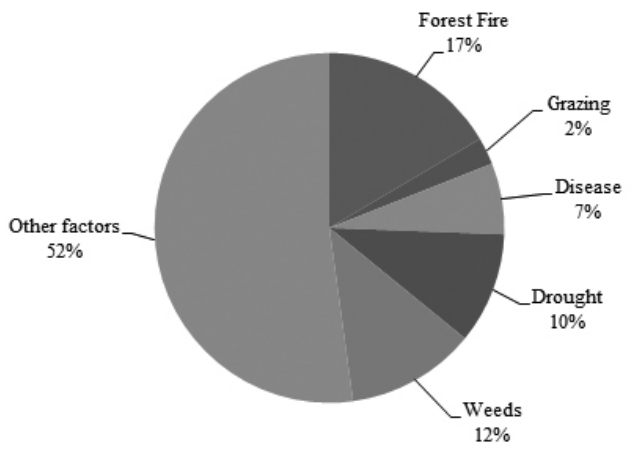

Fig. 2: Causes of seedlings mortality

\section{Discussion}

\section{Plantation survival}

The overall survival percentage of the planted seedlings was found only $58.57 \%$ which was quite lower than the findings of Fonzen (1986). The average survival rate of two-years plantation was $73.7 \%$ with a range of $42 \%$ to $94 \%$ in Palpa district (Fonzen, 1986). Bashyal and Demanski, (1990) found that the survival rate of seedlings planted in private lands of Dang and Salyan districts was $60.5 \%$ after three years. According to Ghimire and Erling (1990), overall survival percentage of seedlings was $63.8 \%$ in 14 districts. The average survival percentage of seedlings recorded by Sherpa (1996) was $66.9 \%$.

The survival rate of four-years and one-year A. lakoocha in farmer's land varied from $15 \%$ to $60 \%$ in Community Forestry Development Project (Campbell and Bhattarai, 1983). Jackson (1994) stated that A. lakoocha is more suitable for planting by individual farmers than in community plantations. In our study, the survival rate of $A$. lakoocha was just $34 \%$ at the end of first year which is similar to Jackson (1994), as it requires fertile soil for good growth and a lot of care and attention after planting.

Neil (1990) found that survival percentage of $F$. semicordata plantation in Palpa district was $77 \%$. The survival rate of $F$. semicordata planted during monsoon was about $90 \%$ but it was only $58 \%$ for this species planted in winter (Sherpa et al., 1992). In contrast to these findings, very low survival rate $(35.28 \%)$ of $F$. semicordata was found in our study. As F. semicordata is a palatable species and in our case the plantation was damaged by browsing. From the discussion with the local people, it was also found that seedlings of this species were not in good condition at the time of planting due to transportation from long distance.

At Kadambas (1500 m), Sindhupalchok district, the survival of 28-months old C. axillaris plants was higher (80\%) (Jackson, 1994) but our study recorded only $42.9 \%$ survival which could be due to poor quality of seedlings.

The survival of the $M$. champaca seedlings was found good (75\%) in our study which is similar to the findings of Shrestha and Gautam (1991). They found that the survival rate of five and seven year old $M$. champaca plants was $79 \%$ and $75 \%$, respectively in Parbat district.

The survival of $P$. wallichiana has been good at altitude over $2000 \mathrm{~m}$ but moderate to poor below $1600 \mathrm{~m}$ (Jackson, 1994). According to Joshi (1985), the survival of P. wallichiana was $89 \%$ at Thulo Chaur (2250 m), Mustang district. Further, the survival rate of $P$. wallichiana was found $64 \%, 89 \%$ and $91 \%$ at Lower Nagarkot $(1700 \mathrm{~m})$, Tistung (1900 m) and Upper Nagarkot (2000 m), respectively (Jackson, 1994). This trend shows that survival rate greatly decreases with decrease in altitude from $2000 \mathrm{~m}$. In our study site, the seedlings of $P$. wallichiana were completely damaged due to fire but discussion with local people revealed that there was considerable good survival before fire occurrence, as the plantation site is around $2000 \mathrm{~m}$.

At Tistung (1900 m), field trials of $F$. auriculata established up to 1985 failed completely while the later plantations had $50 \%$ and $87 \%$ survival rate in open land and under shade of pines, respectively (Jackson, 1994). He also mentioned that the survival rate of this species found higher if planted under the shade of pine than in the open area. Joshi and Sherpa (1992) found that the survival rate of this species also varied with the time of plantation. They recorded $100 \%$ survival for seedlings planted in May, June, August and September; $75 \%$ in October and $41 \%$ in April at Pakhribas (1700 m), Dhankuta district. In our study site, plantation of $F$. auriculata was carried out in June/July and hence fairly higher rate of survival $(72.78 \%)$ was found. Our finding is similar to Jackson (1994) where he stated 70\% survival of 28 months old $F$. auriculata planted 
under pine at Sangachowk, Sindhupalchok district. As $F$. auriculata seedlings were planted in an open area of four CFs without applying fertilizer. The survival rate of this species can be increased further by planting under pine and applying fertilizer.

The survival rate of $T$. ciliata $(59 \%)$ in our study is similar to the findings of Grob (1982) and Ghimire and Nielson (1985). According to Grob (1982), the survival percentage of $T$. ciliata was $75 \%$ in March for seedlings planted in the previous monsoon, while the survival rate was only $43 \%$ in 1983/84 at the same plantation (Ghimire and Neilson, 1985). This species grows well in moist fertile soil (Jackson, 1994), hence the lower survival rate $(59.33 \%)$ in our study could be due to drought and infertile soil.

The survival percentage of $50 \%$ and above is considered as satisfactory by Pakistan Forest Institute (PFI, 2013). Our study showed 58.57\% survival percentage, which could be considered as satisfactory. Discussion with officials of the District Forest Office revealed that in this case seedlings were distributed to plant in selected CFUG sites only after field verification whether sites and pits were prepared or not. But in most of the other cases plantation was carried out without preparing sites and pits. They mentioned that survival rate in other communities could be lower than the studied CFUGs.

\section{Causes of mortality}

Among the various factors identified for seedling mortality, small size and unhealthy seedlings and careless in transportation and handling of seedlings caused $52 \%$ mortality. This result was found similar to findings of the survey carried out by the Community Forestry Development Project in 1982/83, where the causes of about $40 \%$ seedling mortality were due to small size or poor health of the seedlings at the time of planting (Campbell and Bhattarai, 1983; Jackson, 1994).

Moisture stress was the leading cause of seedling mortality, as this accounted for $76 \%$ in Dang and $68 \%$ in Salyan districts (Bashyal and Demanski, 1990). Our finding was contrasted with their findings as drought only accounted for $10 \%$ mortality of seedlings. The sites had sufficient moisture for seedlings so moisture stress was not the leading cause of mortality in our study. Sherpa
(1996) identified livestock damage as the main cause and other causes were drought, unsuitable site, fire, landslide and frost. Ghimire and Erling (1990) identified the three main causes for seedling mortality which were species selection, size of seedling and livestock damage. The factors such as poor quality seedlings, improper site selection, improper planting methods and transportation damage contribute directly to moisture stress (Sherpa, 1996), however, these factors are difficult to determine and were not recorded. Bashyal and Demanski (1990) found that the grazing accounted for $20 \%$ and $18 \%$ seedling mortality in Dang and Salyan districts, respectively. In our study, grazing was not found a serious problem for seedling mortality as compared to the other factors. Protection of plantation carried out under pine forest from fire can improve the survival. Planting of healthy and vigorous seedlings can improve the survival rate of seedlings, so care must be given to produce such seedlings. Similarly care should be taken during handling and transportation to increase the survival of seedlings.

\section{Conclusions and recommendations}

The overall survival rate of different species in fourteen CFs in Parbat district was found to be $58.57 \%$, which is satisfactory but there is variation in survival rate among eleven species. Care must be given to improve the survival rate of those species with low survival rate. Poor health of seedlings, and carelessness in transportation and handling were found the most influencing factors in mortality of the seedlings. Other factors viz. forest fire, weeds, drought, disease and grazing were also affected the survival of different species in plantations. To improve the survival status of the plantations, regular monitoring, use of large sized seedlings, site preparation and protection from fire, grazing and regular weeding are recommended. Assessment of the survival status of different species in different ecological range is also recommended for further studies.

\section{References}

Acharya, R. and Paudel, G. 2016. Implementation status of community adaptation plans: a case study from Parbat District, Nepal. International Journal of Environment 5 (3): $119-126$.

Bashyal, H. P. and Demanski, S. S. 1990. Report 
on the Private Planting Survival Survey in Dang and Salyan Districts of Rapti Zone. Report submitted to the Project Coordinators office of the Rapti Development Project.

Campbell, J. G. and Bhattarai, T. N. 1983. Plantation Survival, Private Planting, Improved Stove Use and Knowledge Increase in Community Forestry, Results from On-going Evaluation Surveys 19821983. Community Forestry Development Project, Nepal HMG/UNDP/FAO.

Carter, A. S. and Gilmour, D. A. 1989. Increase in tree cover on private farm land in central Nepal. Mountain Research and Development 9 (4): 381-391.

DFO. 2016. Monitoring and Evaluation Report of Community Forests. District Forest Office, Parbat, Nepal.

DoF. 2016. Annual Development Programs for the Fiscal Year 2016/2017. Department of Forests, Kathmandu, Nepal.

DFO. 2012. Monitoring and Evaluation Report of Community Forests. District Forest Office, Parbat, Nepal.

Fonzen, P. 1986. Survey of the Afforestation Survival Rates in Palpa District, 1985/86. District Forest Office, Palpa, Tinau Watershed Project, Nepal.

Ghimire, M. P. and Erling, M. N. 1985. Plant Survival and Private Planting Results from On-going Evaluation Surveys 1983-1984. Community Forestry Development Project, Nepal HMG/UNDP/FAO.

Ghimire, M. P. and Nielson, E. M. 1985. Plantation Survival and Private Planting Results from On-going Evaluation Surveys, 1983-84. Miscellaneous Document No. 31. Community Forestry Project, Kathmandu, Nepal.

Grob, P. 1982. Bare Root Planting in Pokhara Forest Division. Report Submitted to the Community Forestry and Afforestation Division, Department of Forests, Nepal.

Jackson, J. K. 1994. Manual of Afforestation in Nepal Volume I and II. Second edition. Forest Research and Survey Center, Ministry of Forests and Soil Conservation, Nepal.

Joshi, L. and Sherpa, S. L. 1992. "Preliminary Results of Some Fodder Research Activities at Pakhribas Agricultural Centre" paper presented at the Fourth Working Group Meeting on Fodder Trees, Forest Fodder and Leaf Litter, Kathmandu, 3-5 December, 1991.

Joshi, R. B. 1985. An Interim Report on Tree Species Trials in RCUP Area. Unpublished report.

Paudel, G. 2015. Forest resource income variation in mid-hills of Nepal: a case study from two CFUGs of Parbat district, Nepal. International Journal of Environment 4 (3): $1-10$.

PFI. 2013. Plantation Survival Rate and Impact Assessment of Watershed Management Interventions for the past 10 years (1995005) in Azad Jammu and Kashmir. Pakistan Forest Institute, Pakistan.

Neil, P. E. 1990. Some promising early species results from the bhabar terai. Banko Janakari 2 (3): 223-228.

Sherpa, S. L. 1996. Tree survival as a means to evaluate private block plantations in the midhills of eastern Nepal. Banko Janakari 6 (2): 74-78.

Sherpa, S. L., Joshi, L. and Upadhyay, M. 1992. Interim Report on Silvicultural Research Trials. Working Paper, Pakhribas Agricultural Centre, Dhankuta, Nepal.

Shrestha, R. K. and Gautam, N. 1991. Evaluation of LRARC Community Planting in Parbat District. Technical Paper No. 2/91, Lumle Agricultural Research Centre, Kaski, Nepal. 